\title{
1 Idealized Romantic Love, Legal Issues, and Patriarchic Exploitation: An Introduction to Historical and Literary Marriage Discourses
}

\begin{abstract}
The latest ... dilemma I've encountered is a big one. Until I told my friends I was getting married, I didn't know marriage and feminism could be considered mutually exclusive. I mean, just because a bride's engagement ring is a symbol of ownership, and just because changing her name erases her identity as a separate individual, and just because the whole thing is ludicrously assumed to be the woman's domain... ${ }^{1}$
\end{abstract}

The British journalist and feminist Laura Bates here describes a marriage discourse that can be observed since and traced back to the 19th century. Marriage is often related to a romanticized image of love, due to which it is considered the final union of two lovers or the highest stage of a love relationship. ${ }^{2}$ On the other hand, very often marriage is disadvantageous for women and represents a form of patriarchic exploitation. Another question Bates asks in her reflection consequently points to one basic dilemma: "Can a woman who's fought for equality and respect, against sexism and misogyny, become a bride?"3 Of course, "[i]t’s not easy to go about your daily feminist business without encountering multiple dilemmas," ${ }^{4}$ but when it comes to love, expressed by a legal union, i.e. marriage, that has been used by men to suppress women for centuries, the dilemma turns into a crux. What has been the backbone of the private form of living, i.e. the family, and the traditional criteria for living together as a couple and/or family

1 Laura Bates, "How to Have a Feminist Wedding," The Guardian, June 28, 2014, https://www. theguardian.com/lifeandstyle/2014/jun/28/can-a-feminist-be-a-bride-laura-bates.

2 The present anthology does predominantly apply a concept of marriage and family that is Western per se, and and also functioned as an instrument of colonial domination, especially in regions where such concepts did not exist before the cultural penetration by expanding European powers. For a discussion of marriage as a political element in a colonial context see, among others, Margot Lovett, "On Power and Powerlessness: Marriage and Political Metaphor in Colonial Western Tanzania," The International Journal of African Historical Studies 27, no. 2 (1994): 273-301; Tim Fulford, "Poetic Flowers/Indians Bowers," in Romantic Representations of British India, ed. Michael Franklin (New York: Routledge, 2006), 113-130, especially 61-63. 3 Bates, "How to Have a Feminist Wedding."

4 Ibid. 
have changed over the last decades in particular. ${ }^{5}$ The Slovenian philosopher Slavoj Žižek also pointed to some problems related to marriage and argued that "beneath the surface of the standard bourgeois notion of marriage lurk many unsettling implications," especially since "we humans no longer just make love for procreation, we get involved in a complex process of seduction and marriage by means of which sexuality becomes an expression of the spiritual bond between a man and a woman, and so forth."6

Along with the changes to what we have considered marriage to be since the early 19th century, a feminist debate about it developed and, as American philosopher Debra B. Bergoffen outlined, “[t]o date most feminist discussions of marriage have been either critical or reactive. Having declared that it is immoral to treat married women as property and unjust to position the wife as subject to the husband, feminists have either rejected the institution of marriage as exploitive or argued that they as individuals have found ways to make marriage work." She consequently argues that "[i]t is not enough for feminists who value marriage to declare that marriage can escape its patriarchal trappings. To reclaim marriage for feminists we need to do more. We need to make the case that patriarchal marriage is a perversion of the meaning of marriage and that this perversion is of concern to feminists." As marriage nowadays determines multiple levels of a relationship between people, i.e. "the erotic, the ethical, and the political," 9 the discourse about marriage needs to take different aspects of it into account when defining the necessities for change with regard to the character and structure of the marital union of the future. Since marriages are legally and socially "seen as a prerequisite to the provision of certain rights and material benefits"10 that are determined by societies in their specific chronological contexts, they are also considered "a public institution that creates a right to private sexual relations, and yet is defined by public policy." 11 The famous US law professor William Eskridge, Jr. highlighted correctly in this regard that "marriage

\footnotetext{
5 Anja Steinbach, “Mutter, Vater, Kind: Was heißt Familie heute?” Aus Politik und Zeitgeschichte 67, no. 30 - 31 (2017): 5. Also see Pamela J. Smock, "The Wax and Wane of Marriage: Prospects for Marriage in the 21st Century," Journal of Marriage and Family 66, no. 4 (2004): 966-973.

6 Slavoj Žižek, “Hegel on Marriage,” E-Flux Journal 34 (2012): 1, accessed March 4, 2021, http:// worker01.e-flux.com/pdf/article_8951758.pdf.

7 Debra B. Bergoffen, “Marriage, Autonomy, and the Feminine Protest," Hypatia 14, no. 4: The Philosophy of Simone de Beauvoir (1999): 18.

8 Ibid.

9 Ibid., 19.

10 Jyl Josephson, “Citizenship, Same-Sex Marriage, and Feminist Critiques of Marriage,” Perspectives on Politics 3, no. 2 (2005): 270.
}

11 Ibid. 
is an institution that is constructed, not discovered by societies." 12 This means that the role marriages are supposed to play for individuals and societies as a whole need to be continuously debated, and marriage-related discourses represent a source to better understand the history of a given society in a specific time frame and can be used to analyze formerly existent norms and values related to this form of human relationship. These changes of marriage in regard to norms and social practices have also been stressed by legal scholar Renata Grossi, who argues that " $[\mathrm{m}]$ arriage has meant different things at different times. It has transmogrified from being a religious sacred institution to a contractual legal one, from a patriarchal institution to a more equal partnership based on freedom and equality."13

Very often, the patriarchal social structure is identified as one of the core issues for marriage discourses ${ }^{14}$ as it has caused many problems for women all around the globe. A long history of forced marriages, ${ }^{15}$ the economic exploitation of women who are married, as criticized and legally challenged by feminists since the 19th century, ${ }^{16}$ and the issue of abuse within marriage are major concerns about the concept as such. Women, whether feminist or anti-feminist, and men, often representing the patriarchic system that was reluctant to accept change, struggled about what marriage meant as well as if and how it could be ended, especially by wives who were demanding to get divorced. ${ }^{17}$ However, not only is the marriage discourse complicated by the issue's public and private implications but also "questions raised by same-sex marriage ... [indicate] a need to rethink many aspects of the legal regulation of families as they affect democratic citizenship." ${ }^{18}$ It is therefore not surprising, as political scientist Jyl Joseph-

12 William N. Eskridge, Jr., “A History of Same-Sex Marriage,” Virginia Law Review 79, no. 9 (1993): 1485, cited in Renata Grossi, Looking for Love in the Legal Discourse of Marriage (Canberra: Australian National University Press, 2014), 17.

13 Grossi, Looking for Love, 17.

14 Mary Becker, "Patriarchy and Inequality: Towards a Substantive Feminism," University of Chicago Legal Forum 1 (1999): 23.

15 E. g. in the UK. See Sundari Anitha and Aisha Gill, "Coercion, Consent and the Forced Marriage Debate in the UK,” Feminist Legal Studies 17 (2009):165-184. For a more global perspective of the issue, see in particular Kaye Quek, Marriage Trafficking: Women in Forced Wedlock (London: Routledge, 2018).

16 Mary Ziegler, "An Incomplete Revolution: Feminists and the Legacy of Marital-Property Reform," Michigan Journal of Gender \& Law 19, no. 2 (2013): 261.

17 For a detailed discussion of this "silent revolution" in the United States, see Herbert Jacob, Silent Revolution: The Transformation of Divorce Law in the United States (Chicago: University of Chicago Press, 1988).

18 Josephson, “Citizenship,” 269. 
son further remarks, that "[a]dvocates of same-sex marriage compare their quest to those of other social movements, particularly the civil rights movement, that sought equal status as citizens before the legal institutions of the state."19 A continuation of the patriarchic instrumentalization of marriage norms would therefore not only prevent women from acting as equal citizens with the same political and social rights as men but also representatives of the LGBTQ+ community, whose ostracization from equal marriage rights would represent a limitation of their rights as individuals as well. In this regard, one can only agree with the evaluation of marriage of Josephson, who argues that it "has a significant place in our understanding of responsible citizenship in a democratic polity"20 and that "[m]arriage has become a centerpiece for both opponents and proponents of greater rights for the members of the gay, lesbian, bisexual and transgender community."21 It took, however, a long time for such aspects to become part of the marriage discourse, which itself was not very prominent or taking place in the form of a truly public debate before the 19th century.

\section{Early Debates about Marriage}

Before the Enlightenment stimulated debates about existent social norms like marriage, ${ }^{22}$ the demands for and the social role of the latter, which also means the position of women as part of such relations or unions, were solely determined by men, who used marriages in many ways as a repressive measure to keep women in their unequal social and political position. While marriages were considered an important element of diplomacy as well lineage protection and legitimization in antiquity, ${ }^{23}$ in the Middle Ages, "the Roman Church count-

19 Ibid., 270.

20 Ibid., $269-270$.

21 Ibid., 269.

22 For some recent works about debates about marriage related to the Enlightenment see, among others, E. Claire Cage, Unnatural Frenchmen: The Politics of Priestly Celibacy and Marriage, 1720-1815 (Charlottesville, VA: University of Virginia Press, 2015); Edward T. Potter, Marriage, Gender, and Desire in Early Enlightenment German Comedy (Cambridge: Cambridge University Press, 2013); Sian Reynolds, Marriage and Revolution: Monsieur and Madame Roland (New York/Oxford: Oxford University Press, 2012).

23 For a detailed survey of marriage policies in antiquity, see Sabine Müller's chapter in the present volume. Marriage remained an important diplomatic element until modern times and secured ties between European rulers. The Habsburg Empire's diplomacy in particular used marriage as an important cornerstone of its political relations in Europe. See Paula Sutter Fichtner, 
ed the marital union of man and woman among the seven sacraments, had placed it under its special protection, thoroughly regulated betrothal and divorce with canon law, and laid down norms for sexual behavior in and outside of marriage." ${ }^{24}$ In later centuries, the Church continued to control the perception of and rules for marriage when "papal and episcopal courts ... exercised an enormous influence on the marital behavior of men and women, enforced legally defined impediments to marriage, and drew couples wanting to marry as well as already married couples before ecclesiastical tribunals."25 Throughout medieval times, marriage as such was considered a public issue and legal institution rather than something related to romantic feelings. Although, as Italian historian Silvana Seidel Menchi affirms, "[t]here is no consensus as to exactly what a marriage was in early modern society," it was nevertheless more a legal than a romantic institution because "eroticism and passion are aspects that [were] alien to the traditional marriage" 26 in early modern times. A dichotomy between differing views on marriage, however, existed in the centuries leading from the medieval to the modern period, before the dispute eventually gained importance and became more central in the 19th century. These centuries, to quote Seidel Menchi once more, were-more or less-characterized by two main perspectives on marriage:

The tension between the model of the disciplined marriage and the particularity of individual choices was a constant of European social history from the waning of the Middle Ages until the early nineteenth century. The tendentiously uniform model recommended by the ecclesiastical and secular authorities is counterpoised by a plurality of individual conjugal initiatives. A lively nuptial experimentation paralleled and challenged the norm. The model of a disciplined, regulated, socially conforming marriage, as formulated by jurists and theologians, found itself in competition with a variegated and undisciplined category of marriage, obeying individual impulses and emotions. ${ }^{27}$

From the 18th century, “debates about 'policing the family,' with marriage as its linchpin, through the state" 28 began to intensify. From "a global perspective on

"Dynastic Marriage in Sixteenth-Century Habsburg Diplomacy and Statecraft: An Interdisciplinary Approach,” The American Historical Review 81, no. 2 (1976): 243-265.

24 Ludwig Schmugge, Marriage on Trial: Late Medieval German Couples at the Papal Court (Washington, DC: Catholic University of America Press, 2012), 1-2.

25 Ibid., 2.

26 Silvana Seidel Menchi, "Introduction," in Marriage in Europe, 1400-1800, ed. Silvana Seidel Menchi (Toronto: University of Toronto Press, 2016), 3.

27 Ibid., 7.

28 Julia Moses, "Introduction: Making Marriage 'Modern'," in Marriage, Law and Modernity: Global Histories, ed. Julia Moses (London: Bloomsbury, 2017), 1. 
the modern history of marriage," which is represented in Julia Moses' recently published anthology Marriage, Law and Modernity (2017), this century "witnessed the creation of global marital norms that, to a certain extent, became enshrined in international law." 29 The debates related to the establishment of the new norms "had contradictory effects, enabling love to thrive in various forms, yet discouraging or outright banning certain types of relationships" as, for some of those, defining the new set of norms related to marital relationships was an expression of "modernity." 30

Hence it was not only legal debates that characterized the discourse about marriage, as in the 18th and 19th centuries, philosophers also participated in the discourse about the role of the martial relationship between women and men for the family and society. ${ }^{31}$ For the German philosopher Georg Wilhelm Friedrich Hegel (1770 - 1831), to quote Žižek's evaluation here,

marriage is "a contract to transcend the standpoint of contract": contract is a deal between two or more autonomous individuals, each of whom retains their abstract freedom (as is the case in exchange of commodities), while marriage is a weird contract by means of which the two concerned parties oblige themselves precisely to abandon/surrender their abstract freedom and autonomy and to subordinate it to a higher organic ethical unity. ${ }^{32}$

Hegel therefore endorsed the "'sacrifice of personality' as the only suitable basis for marriage," 33 especially since his idea of the family is not based on equality between men and women. The family Hegel has in mind, according to US women's studies scholar and historian Joan B. Landes, "is not a simple model for politics. He therefore rejects the idea that authority relationships throughout society are homogeneous, a view which underlies the patriarchalist argument that the father's relationship to his wife and children is analogous to the king's relationship to his subjects." 34

For Hegel, the family can also not be separated from the society it exists in, which is why he "rejects the proposition that the family constitutes a wholly independent sphere of social existence, a refuge from an unpleasant social

29 Ibid.

30 Ibid.

31 For the 18th century, see Marlene LeGates, "The Cult of Womanhood in Eighteenth-Century Thought," Eighteenth-Century Studies 10, no. 1 (1976): 21-39.

32 Žižek, "Hegel on Marriage," 2. The direct Hegel quotes refer to Philosophy of Right (1820), accessed March 4, 2021, http://www.marxists.org/reference/archive/hegel/works/pr/prfamily.htm. 33 Kathryn Wilkinson, "Hegel, The Sacrifice of Personality and Marriage” (PhD diss., University of Sheffield, 2006). For a more detailed discussion of this sacrifice, see ibid., 111-162.

34 Joan B. Landes, “Hegel’s Conception of the Family,” Polity 14, no. 1 (1981): 5. 
world." 35 In his work Philosophy of Right (1820), he nevertheless points to problems of legal contracts in their relation to marriage: "[T]hough marriage begins in contract, it is precisely a contract to transcend the standpoint of contract, the standpoint from which persons are regarded in their individuality as self-subsistent units." ${ }^{36}$ Hegel therefore shows some ambivalence in his elaborations about marriage, as this relationship tends to "transcends the standpoint from which man and wife are deemed to have property in each other, especially in one another's sexual faculties." ${ }^{37}$ The described ambivalence expressed about the nature of marriage in Hegel's writings consequently points to the discourses of his time and provided what German-American scholar Rudolf J. Siebert called "[t]he Origin of Subjective Freedom." ${ }^{38}$ Regardless of this origin, Hegel continued to consider women and men to be different with regard to their nature. In his Philosophy of Right, Hegel argued the following:

\begin{abstract}
Women are capable of education, but they are not made for activities which demand a universal faculty such as the more advanced sciences, philosophy, and certain forms of artistic production. Women may have happy ideas, taste, and elegance, but they cannot attain to the ideal. The difference between men and women is like that between animals and plants. Men correspond to animals while women correspond to plants because their development is more placid and the principle that underlies it is the rather vague unity of feeling. When women hold the helm of government, the state is at once in jeopardy, because women regulate their actions not by the demands of universality but by arbitrary inclinations and opinions. Women are educated - who knows how? - as it were by breathing in ideas, by living rather than by acquiring knowledge. The status of manhood, on the other hand, is attained only by the stress of thought and much technical exertion. ${ }^{39}$
\end{abstract}

Although Hegel's works and thoughts are still important today and kept their actuality in many regards, ${ }^{40}$ these views are nevertheless now outdated. However, they show how marriage and the role of the two sexes within it were perceived in the first third of the 19th century.

Beyond the philosophical level of marriage discourses, the relationships themselves and the motives to engage in them were and still are very often relat-

35 Ibid., 6.

36 Cited in ibid., 8.

37 Ibid., 10.

38 Rudolf J. Siebert, Hegel's Concept of Marriage and Family: The Origin of Subjective Freedom (Washington, DC: University Press of America, 1979).

39 Cited in Landes, "Hegel's Conception of the Family," 22.

40 As exemplars, see, among others, Marina F. Bykova and Kenneth R. Westphal, eds. The Palgrave Hegel Handbook (Cham: Palgrave, 2020); Slavoj Žižek, Hegel im verdrahteten Gehirn, trans. Frank Born (Frankfurt am Main: Fischer, 2020). 
ed to the "main economic behaviors of workers and consumers."41 American economist Shoshana Grossbard therefore correctly emphasizes that multiple questions and the way marriage might relate to them or provide specific answers determines the human decision to legally bond with another: "How much people work, how much they earn, what kind of work they engage in is partially motivated by their marriage goals and commitments." 42 That especially working-class women were driven into marriage by their exploitative working conditions, just to be exploited as mothers and workers once fulfilling their role as wives, was criticized early on by leading figures of the socialist and workers' movements.

\section{Marriage Roles and Social Questions}

The German Social Democrat August Bebel (1840 -1913) emphasized the capitalist nature of marriage in his work Woman and Socialism (1879)..$^{43} \mathrm{He}$ argues that "[m]onogamic marriage as has been sufficiently shown, is the outcome of the system of gain and property that has been established by bourgeois society, and therefore undoubtedly forms one of its basic principles." ${ }^{44}$ In this important work, Bebel outlined that "marriage, which depends upon the bourgeois system of property, is a more or less forced relation, having many disadvantages, and frequently fulfilling its purpose only insufficiently or not at all." ${ }^{45}$ These considerations were essential for the re-evaluation of marriage in the late 19th century, and many feminists who also shared a political identity of the left would emphasize this issue as part of the larger "woman question" that they increasingly connected with a female view on the ongoing class struggle. ${ }^{46}$ Another important representative of the political left who similarly emphasized the problems related to marriage as a form of exploitation was Friedrich Engels $(1820-1895) .{ }^{47}$ In his

41 Shoshana Grossbard, The Marriage Motive: A Price Theory of Marriage (New York: Springer, 2015), 5.

42 Ibid.

43 August Bebel, Woman and Socialism (New York: Socialist Literature Co., 1910 [1879]), accessed March 4, 2021, https://www.marxists.org/archive/bebel/1879/woman-socialism/index. htm.

44 Ibid., chap. VIII.

45 Ibid.

46 For a more detailed discussion of this connection, see Vincent Streichhahn and Frank Jacob, eds., Geschlecht und Klassenkampf: Die "Frauenfrage" aus deutscher und internationaler Perspektive im 19. und 20. Jahrhundert (Berlin: Metropol, 2020).

47 On Engels's position toward and his role in the debate of the "woman question" during the 19th century, see Vincent Streichhahn, “Friedrich Engels: From the ‘Woman Question' to Social 
work The Origin of the Family, Private Property and the State (1884), Engels characterized marital relationships as follows:

\begin{abstract}
Monogamous marriage was a great historical step forward; nevertheless, together with slavery and private wealth, it opens the period that has lasted until today in which every step forward is also relatively a step backward, in which prosperity and development for some is won through the misery and frustration of others. It is the cellular form of civilized society, in which the nature of the oppositions and contradictions fully active in that society can be already studied. ... But a second contradiction thus develops within monogamous marriage itself. At the side of the husband who embellishes his existence with hetaerism stands the neglected wife. And one cannot have one side of this contradiction without the other, any more than a man has a whole apple in his hand after eating half. But that seems to have been the husbands' notion, until their wives taught them better. With monogamous marriage, two constant social types, unknown hitherto, make their appearance on the scene the wife's attendant lover and the cuckold husband. The husbands had won the victory over the wives, but the vanquished magnanimously provided the crown. Together with monogamous marriage and hetaerism, adultery became an unavoidable social institution denounced, severely penalized, but impossible to suppress. ${ }^{48}$
\end{abstract}

Many women and men would eventually share such views and criticize marriage as a form of patriarchic exploitation and suppression. Although they had been contested by men as well, both of these elements were particularly harsh for the women who got married, or as British historian Philippa Levine expressed it:

\begin{abstract}
Marriage, for the nineteenth-century woman, was perhaps the single most profound and far-reaching institution that would affect the course of her life. For the woman who did not marry, whether by choice or by chance, spinsterhood marked her as one of society's unfortunates, cast aside from the common lot of the sex. For the woman who did enter wedlock, marriage spelled, simultaneously, a loss of freedom in both political and financial matters, perhaps domestic drudgery and frequent pregnancy, but undoubtedly a clear elevation in social status. ${ }^{49}$
\end{abstract}

Marriage expressed power over many women's lives, as, to quote Levine once more, "[i]t was undoubtedly one of the major agencies of socialization to

Reproduction Theory,” in Engels @ 200: Reading Friedrich Engels in the 21st Century, ed. Frank Jacob (Marburg: Büchner, 2020), 235-270.

48 Friedrich Engels, Der Ursprung der Familie, des Privateigenthums und des Staats (HottingenZurich: Verlag der Schweizerischen Volksbuchhandlung, 1884). English text taken from https:// www.marxists.org/archive/marx/works/1884/origin-family/ch02d.htm, accessed March 4, 2021. 49 Philippa Levine, “'So Few Prizes and So Many Blanks': Marriage and Feminism in Later Nineteenth Century England,” Journal of British Studies 28, no. 2 (1989): 150. Although Levine focused her evaluation on Victorian England, it can be applied for women in other national contexts of the 19th century as well. 
which women were exposed; the pressures it imposed were enormously persuasive and difficult to resist." 50 The contestation of marriage by women during the 19th century was nevertheless taking place and consequently one of the elements that would stimulate the genesis of the "First Wave" feminists in many national contexts. ${ }^{51}$

During the 19th century, the discourses about marriage intensified, especially since they "were really about who should be included as full citizens in the polity" 52 and represented a stronger demand by women to be treated equally. This also involved the debate about the legal right to divorce. In the 18th century, in his posthumously published work The History of the Pleas of the Crown (1736), the influential English barrister and judge Sir Matthew Hale (1609-1676) emphasized the right of men in marital relations by arguing that husbands cannot be considered guilty for "a rape committed by himself upon his lawful wife, for by their mutual matrimonial consent and contract the wife hath given herself in this kind unto her husband which she cannot retract." 53 Divorce, which had long not been an option for women at all ${ }^{54}$ and controlled exclusively by the Church, was secularized during the 19th century, although "[t]he grounds upon which divorce could be granted were different for men and women (the infamous divorce double standard)." 55 Step by step, and in accordance with other rights women began to demand, ${ }^{56}$ "married women had won a number of important rights in relation to the ownership of property and the right to leave a marriage." 57

50 Ibid.

51 Olive Banks, Becoming a Feminist: The Social Origins of "First Wave" Feminism (Brighton: Wheatsheaf Books, 1986); Valerie Sanders, "First Wave Feminism," in The Routledge Companion to Feminism and Postfeminism, 2nd ed., ed. Sarah Gamble (London: Routledge, 2001), 15-24. 52 Josephson, “Citizenship," 270.

53 Matthew Hale, History of the Pleas of the Crown 1736, vol. 1, ed. Peter R. Glazebrook (London: Professional Books, 1971), 629, cited in Grossi, Looking for Love, 20. In Germany, to name just one example here, rape in a marriage could not be legally charged until 1992. For a broader contextualization, see Melanie Randall, Jennifer Koshan and Patricia Nyaundi, eds., The Right to Say No: Marital Rape and Law Reform in Canada, Ghana, Kenya and Malawi (Oxford: Hart, 2017). 54 In Britain, between 1670 and 1857, only four of the 325 people who successfully obtained a divorce were women. Grossi, Looking for Love, 22.

55 Ibid.

56 For a survey of women's struggles to gain political rights, first and foremost the right to vote, see, among others, Hedwig Richter and Kerstin Wolff, eds., Frauenwahlrecht: Demokratisierung der Demokratie in Deutschland und Europa (Hamburg: Hamburger Edition, 2018).

57 Grossi, Looking for Love, 23. 


\section{The 20th Century and the Struggle for Equality}

Once the "First Wavers" had begun their quest for more political and social equality, it was the 20th century that witnessed substantial changes. Marriage and its image as such seemed to have reached a crisis around $1900^{58}$ and, as Austrian historian Christa Putz emphasized, "[i]t could not be overlooked that the zeal of sex researchers was also driven by a larger social problem. Around 1900 it is a question of 'saving' marriage or at least making its crises manageable."59 The traditional relationship between man and woman was supposed to face a general crisis, as represented by "[t]he legal disadvantage of women in marriage, the increase in the divorce rate, the decline in marital births and the failure of romantic ideals in practice." ${ }^{60}$ This was also related to the change of the considerations about marriage, love, and sex. ${ }^{61}$ Especially sexual passion as part of a marital relationship was debated as well, and in the early 1900s, guide books, reflecting feminist demands, "no longer teach spouses how to curb their lust and, if possible, subordinate it to conception, but how it could succeed in igniting passion and maintaining it permanently. It is downright prescribed for the couple to realize themselves sexually in marriage."62

Marital relations and how they could be emotionally, socially, and politically reframed were also a subject in literary works that began to focus on such relationships. ${ }^{63}$ "New Woman fiction" challenged traditional images of women in literature, and the new female heroines that were presented also struggled with ex-

58 Christa Putz, Verordnete Lust: Sexualmedizin, Psychoanalyse und die "Krise der Ehe," 1870 1930 (Bielefeld: Transcript, 2011), 123-154.

59 Ibid., 16.

60 Ibid.

61 Christina Simmons, Making Marriage Modern: Women's Sexuality from the Progressive Era to World War II (New York: Oxford University Press, 2009), 58-104.

62 Putz, Verordnete Lust, 16. Also see Lesley Hall, “'Good Sex': The New Rhetoric of Conjugal Relations," in The Facts of Life: The Creation of Sexual Knowledge in Britain 1650-1950, eds. Roy Porter and Lesley Hall (New Haven, CT: Yale University Press, 1995), 202-223.

63 One example would be H. G. Wells, Marriage (Auckland, NZ: The Floating Press, 2011 [1912]). Wells in a way describes Marjorie, the female protagonist of his novel, as resembling the fact that women were demanding more than society was actually offering them: "That was the visible Marjorie. Somewhere out of time and space was an invisible Marjorie who looked out on the world with those steady eyes, and smiled or drooped with the soft red lips, and dreamt, and wondered, and desired.” Ibid., 8. 
istent marital norms. ${ }^{64}$ Literature studies scholar Sevinç Elaman identified a "juxtaposition of a multiplicity of conflicting voices on the New Woman question" in the early 20th century, "particularly as these are expressed in the heroines' inner dilemmas and conflicts and around the issues of marriage, divorce and sexuality." ${ }^{65}$ Elaman further emphasized that "[t]he New Woman was one of the most dramatic symbols of the crisis of gender relations that occurred during the fin-de-siècle period in a number of societies. Her image was first brought to public attention worldwide in the 1890s as she became a subject of discussion and controversy in magazines, periodicals and newspapers." ${ }^{66}$ Dichotomic gender norms, including the ones related to emotions ${ }^{67}$ or the female capacity with regard to work, were more and more contested, especially by transnational events like the First World War that challenged not only political systems and social orders ${ }^{68}$ but also the existent gender roles,${ }^{69}$ including traditional considerations about marriage. ${ }^{70}$

The First World War nevertheless also laid the ground for a hyper-masculinity $^{71}$ that would determine a reversed course against the emancipatory efforts that had been achieved so far. ${ }^{72}$ The interwar period as well as the Second

64 Sevinç Elaman, “A Feminist Dialogic Reading of the New Woman: Marriage, Female Desire and Divorce in the Works of Edith Wharton and Halide Edib Adıvar" (PhD diss., University of Manchester, 2012), 4.

65 Ibid.

66 Ibid., 9. On the "New Woman" narrative and some of its main represenatatives, see Ann Heilmann, New Woman Strategies: Sarah Grand, Olive Schreiner, Mona Caird (Manchester: Manchester University Press, 2004).

67 Manuel Borutta and Nina Verheyen, "Vulkanier und Choleriker? Männlichkeit und Emotion in der deutschen Geschichte 1800 - 2000,” in Die Präsenz der Gefühle: Männlichkeit und Emotion in der Moderne, eds. Manuel Borutta and Nina Verheyen (Bielefeld: Transcript, 2010), 12.

68 For a global perspective on these protests, see Marcel Bois and Frank Jacob, eds. Zeiten des Aufruhrs (1916-1921): Globale Proteste, Streiks und Revolutionen gegen den Ersten Weltkrieg und seine Auswirkungen (Berlin: Metropol, 2020).

69 See, among others, Susan A. Grayzel, Women's Identities at War: Gender, Motherhood, and Politics in Britain and France During the First World War (Chapel Hill, NC: University of North Carolina Press, 1999).

70 Sandra Brée and Saskia Hin, eds., The Impact of World War I on Marriages, Divorces, and Gender Relations in Europe (London: Routledge, 2020).

71 George L. Mosse, The Image of Man: The Creation of Modern Masculinity (New York: Oxford University Press, 1996).

72 On marriage norms during the Second World War, see Ulrike Jureit, "Zwischen Ehe und Männerbund: Emotionale und sexuelle Beziehungsmuster im Zweiten Weltkrieg," WerkstattGeschichte 22 (1999): 61-73. 
World War proved to be disastrous for the emancipatory course of the feminist movements around the globe, and as legal scholar Mary Becker emphasizes,

Human beings, whether men, women, or children, do not flourish when hyper-masculinity is glorified and traditionally feminine qualities (such as care, caretaking, and valuing relationships) are denigrated. Nor do human beings flourish when all males are pressured to adopt hypermasculine attributes and repress feminine ones, and all females are pressured to adopt traditionally feminine attributes and repress masculine ones. ${ }^{73}$

Regardless of such setbacks, feminists, like the sociologist Jessie Bernard (19031996) in her work The Future of Marriage (1972), ${ }^{74}$ argued that the future of marital relationships would rely upon its re-definition to match female demands for a more equal and emancipated form of marriage. Bernard highlighted the continuation of two different forms or norms of marriage: a female one and a male one. ${ }^{75}$ This double standard could cause trouble for the patriarchy, especially "when women in traditional marriages assume a feminist identity, they and their relational expectations change a great deal but their husbands have little interest in changing their beliefs and behaviors," 76 expressing their unease with an emancipated form of relationship that would challenge their ruling position. Feminists have consequently pointed to the exploitative and repressive aspects of marriage, which functioned rather as a means of patriarchic suppression than the fulfillment of romantic ideals.

In addition, the pressure of marital relations on wives is manifold: "Women are the marital partners responsible for a family's emotional intimacy, for adapting their sexual desires to their husbands', for monitoring the relationship and resolving conflict from a subordinate position, and for being as independent as possible without threatening their husbands' status." ${ }^{77}$ While women began to struggle for a better form of marriage, conservative forces, especially male elites, were not willing to change the existent patriarchic norms. ${ }^{78}$ Since the 1990s and early 2000s, the LGBTQ+ community has also demanded changes with regard to the traditional concepts of marriage. ${ }^{79}$ Next to the public debate

73 Becker, "Patriarchy and Inequality," chap. 22.

74 Jessie Bernard, The Future of Marriage (New York: Bantam Books, 1972).

75 Karen R. Blaisure and Katherine R. Allen, "Feminists and the Ideology and Practice of Marital Equality,” Journal of Marriage and Family 57, no. 1 (1995): 5.

76 Ibid.

77 Ibid., 6.

78 William N. Eskridge and Christopher R. Riano, Marriage Equality: From Outlaws to In-Laws (New Haven, CT: Yale University Press, 2020), 113.

79 John Mazurek, The Road to Marriage Equality (New York: Rosen Publishing, 2018), 47-58. 
about same-sex marriage, there were legal implications that were hotly debated, especially in the United States:

\begin{abstract}
Marriage is an institution that many people view as the ultimate commitment between two partners, but it is also a legal institution that confers rights and protections. That is why for most of American history, same-sex partners had been denied something far greater than a piece of paper when they were turned away from their attempts to receive a marriage license. To be denied marriage also meant to be denied protections that included the right to exist as a family unit, the right to make legal decisions as a parent or spouse, and the right to self-govern one's family in a way that is agreeable to the law. ${ }^{80}$
\end{abstract}

Naturally, and not only in the United States, the debates about marriage and the changes achieved, ${ }^{81}$ in relation to its nature and form as well as its meanings and implications, were continued in the late 20th and early 21st centuries and present an ongoing process that is unlikely to stop soon, ${ }^{82}$ as societies are leading fierce debates about gender norms at the moment, especially with regard to the use of an appropriate gendered language. ${ }^{83}$

\title{
Marriage in the 21st Century
}

A new approach toward marriage is already being expressed by a new generation, i.e. the millennials. According to American scholar Brian J. Willoughby,

millennials are approaching marriage with more hesitation and caution than ever before, even if it appears to bring happiness and fulfillment. Marriage, once the clear front-runner when it came to romantic unions, has now come under fire. There are numerous potential hypotheses as to why marriage may have lost its beneficial luster in the last few decades. For our purposes, however, we will focus on perhaps the most lingering yet important potential cause of this shift: that millennials have changed what marriage means and how it works. ${ }^{84}$

80 Ibid., 8.

81 Rebecca Probert, Joanna Miles and Perveez Mody, "Introduction,” in Marriage Rites and Rights, eds. Joanna Miles, Perveez Mody and Rebecca Probert (Oxford: Hart Publishing, 2015), 3. 82 Laura L. Paterson and Georgina Turner, “Approaches to Discourses of Marriage," Critical Discourse Studies 17, no. 2 (2020): 136.

83 Felix Bohr et al., “Ist das * jetzt Deutsch?” Der Spiegel, March 5, 2021, https://www.spiegel. de/panorama/gesellschaft/gendergerechte-sprache-der-kulturkampf-um-die-deutsche-sprachea-ad32de9a-0002-0001-0000-000176138596.

84 Brian J. Willoughby, The Millennial Marriage (London/New York: Routledge, 2020), 10. 
Considering the historical discourses about marriage, this means that there is another and currently evolving "growing tension between the ideal of marriage held in the past and the new approach to marriage." 85 This tension is created "between one's personal ambitions and goals and the marital relationship's needs and goals" 86 and in a way repeats earlier negotiations between those parties who engage in martial relations to secure the best possible but first and foremost equal outcome of such an engagement. What if an essential precondition for such an achievement is the end of toxic patriarchy with regard to marriage?

The question of the ideal marriage is interesting not just for the intellectuals who reflect on it, nor for the state as the organizing institution for marriages, but for all human beings who are interested in a better, i.e. more equal, society. ${ }^{87}$ This also opens the question of whether marriages are needed at all for a future society, although marriage is not at its end yet because it is still a strong aspect of our value system, maybe because human beings still want to rely upon romantic images that are often too far away from the repressive and exploitative realities of marriage. Some works on marriage also point out the "beneficial effects of marriage" that can exist: "Married people are generally healthier; they live longer, earn more, have better mental health and better sex lives, and are happier than their unmarried counterparts. Further, married individuals have lower rates of suicide, fatal accidents, acute and chronic illnesses, alcoholism, and depression than other people." 88 However, it must be emphasized that it is the quality and equality of the marital relationship that guarantees these advantages, not marriage per se. At the same time, as American sociologist Steven L. Nock pointed out, the advantages as such were quite unequal for women and men: "Even though marriage contributes to the well-being of both men and women, husbands are the greater beneficiaries. Men reap greater gains than women for virtually every outcome affected by marriage. When women benefit from marriage, it is because they are in a satisfying relationship; but men appear much less sensitive to the quality of their marriages and gain by simply being married." ${ }^{89}$ Nock therefore clearly pointed to the gender gap within marital relations: “Marriage itself improves men's lives; the quality of the marriage affects women's lives." ${ }^{90}$ This also leads to different gender experiences in relation to marriage,

85 Ibid., 32.

86 Ibid.

87 Elizabeth Brake, Minimizing Marriage: Marriage, Morality, and the Law (Oxford: Oxford University Press, 2012), 1.

88 Steven L. Nock, Marriage in Men's Lives (Oxford: Oxford University Press, 1998), 3.

89 Ibid. Emphasis in the original.

90 Ibid. 
which, of course, must also be considered when taking a look at historical marriage discourses. Women have a reason to challenge the marriage norms of their times, as they were rarely considered equal partners within such relationships. They were systematically put at a disadvantage, one that was legally sanctioned to allow husbands to rule, exploit, and abuse their wives. Without any doubt, as Renata Grossi correctly outlined, “the most decisive of the institution's meanings comes from the fact that it entrenched the dominance of the male/husband, and the complete subordination of the female/wife."91 Historically, marriage meant "in fact a 'civil death' for women, who were treated like children, idiots, criminals and even slaves." 92 One can consequently only agree with Lawrence Stone's dictum that it was, next to economic necessities, only the "skillful resistance of many wives and the compassion and goodwill of many husbands" 93 that kept marriage, especially as a romantic ideal, alive over time.

Whatever the future of marriage and the discourses about it will be, it is essential to abolish its patriarchic nature. For far too long, marriage has continued to reproduce patriarchic norms, ${ }^{94}$ and the generations of the 21 st century will have to end this inequality. As “[m]ost men are aware of women's second shift and its unfairness, but are uninterested in change," 95 it is important that the necessity for change is acknowledged and accepted by a majority of men as well to support, and not in a patronizing way, the establishment of further gender equality, especially with regard to marriage. This also means that feminists need to be fully supported by other political movements, especially from the left, which had failed to do so in the past, particularly since "there is ample evidence of the persistence of sexual violence, gendered discrimination and hostility to feminism across sites of left politics, old and new."96 The image of modern marriage is at the same time too closely related to stereotypes that have remained uncontested for too long and abused by patriarchic elites around the globe. Becker, in this regard, makes it clear that it is important to contest such images and believes that

91 Grossi, Looking for Love, 19.

92 Ibid.

93 Lawrence Stone, Broken Lives: Separation and Divorce in England, 1660-1857 (Oxford: Oxford University Press, 1993), 26, cited in ibid., 19-20.

94 Carol Smart, The Ties that Bind: Law, Marriage and the Reproduction of Patriarchal Relations (London: Routledge, 1984).

95 Becker, "Patriarchy and Inequality," 21-22.

96 Kirsty Alexander, Catherine Eschle, Jenny Morrison and Mairi Tulbure, "Feminism and Solidarity on the Left: Rethinking the Unhappy Marriage Metaphor,” Political Studies 67, no. 4 (2019): 973. 
[b]ecause patriarchy rests on the belief that women and men are essentially different, patriarchy values and rewards women and men for conforming to gender stereotypes. For example, in custody disputes, many courts consider economic stability as a reason for awarding custody to the father, who has been the primary breadwinner throughout the marriage. In contrast, mothers who have worked for wages throughout the marriage, most of whom have also been primary caretakers of the children, often lose custody because they work outside the home. It is important to break the link between sex and valuation. ${ }^{97}$

As mentioned before, it is therefore important to discuss what marriage actually is, and if it continues in the future, what it should look like and what it should stand for. The present anthology in this regard provides some examples from history and literature to show the manifold forms of marriage discourses that have been witnessed in the past.

\section{The Contributions}

The editors hope that the contributions will stimulate further and necessary debates about marriage, no matter if they are related to its institutional and legal aspects or to romantic aspects of an equal union between lovers, regardless of their self-declared and self-expressed gender norms.

The first section of this volume begins with some reflections about marriage discourses with regard to law and politics. Depending on its historical and geographical context, the understanding of marriage could be quite different from our modern day considerations. The contributions in the initial part of the volume will therefore show, that marriage was for centuries a political or legal aspect of human life, but nothing related to romance of human emotions at all. Sabine Müller provides a detailed survey and analysis of the roles of marriage in ancient societies, namely the Persian, Greek, and Roman ones. She shows that marriage has rather been considered a political institution and that it was an expression of alliances, lineage, and legitimization and not related to any romantic images that would later become attached to it by socially constructed narratives. That marriage was rather related to the public order and the display of gender roles followed ideas of order and rule is then discussed by Mariela Fargas Peñarrocha in her chapter on marriage discourses in early modern Spain. As in antiquity, the determination of what marriage was supposed to mean for the public and private order continued to be stipulated by men, securing the rule of the patriarchy. How First Wave feminists would later challenge these traditional struc-

97 Becker, "Patriarchy and Inequality," 51. 
tures is discussed by Marion Röwekamp, who shows how women contested existent legal norms in relation to marriage in Imperial Germany and the Weimar Republic. The section as a whole therefore gives a first impression of how legal aspects of marriage were established, which purposes they served, and what efforts it took to change them.

The second section takes a closer look at some critics of social norms in relation to marriage during the latter part of the "long" 19th century. ${ }^{98}$ Scientists and political activists alike questioned the existent gender relations in the late 1800s and began to actively demand a change, based on their theoretical considerations as well as practical experiences. Vincent Streichhahn opens the section and takes a closer look at the German sociologist Robert Michels (1876-1936) and his Sexual Ethics. Streichhahn locates the latter between the women's movement during the German imperial period and social democracy, showing that marriage discourses politically overlapped and found supporters or stimulated debates in different spheres in the early 1900s. Frank Jacob's analysis of Emma Goldman's (1869-1940) anarcha-feminist views on marriage and sexual liberation further highlights the amalgamation of early or proto-feminist positions with the political ideas of class struggle during the late 19th and early 20th centuries, in which women who represented the broad spectrum of the political left also acted as agents for gender equality, especially with regard to the further advancement of marriage as a truly equal form of relationship. Jowan A. Mohammed's chapter on Mary Hunter Austin (1868-1934) and her struggle against patriarchic norms, especially with regard to the marital relations of women in her times, shows that while this struggle was a political one, it was also expressed in literary works. Like Goldman, Austin reflected on marriage according to her personal experiences, but at the same time in their literary or political writings made clear statements for more gender equality. Mohammed with her analysis thereby bridges the second and the last sections of the present volume.

In the final part, Jamie Christopher Callison, Jessica Allen Hanssen, and Margaret Stetz provide chapters on literary discourses about marriage that show how authors dealt with marriage from the late 19th to the early 21st century and in which ways they used their texts as a way to stimulate and sometimes provoke their readers' thoughts about marriage and what it stood for. The single cobtributions consequently show in what way the literary texts in specific time periods can be read and positioned with regard to their respective take on marriage as

98 Franz J. Bauer, Das "lange” 19. Jahrhundert (1789-1917): Profil einer Epoche, 4th rev. ed. (Stuttgart: Reclam, 2017). 
an important social issue. After a discussion of marriage discourses in interwar Britain based on the poetry of the American writer H.D., i.e. Hilda Doolittle (1886-1961), in which Callison provides a close reading of the motifs of internal transformation and personal sacrifice, Allen Hanssen analyzes The Age of Innocence, the 1920 novel by Edith Wharton (1862-1937). Last but not least, Stetz shows how marriage-related images were combined with feminism and fashion in Ilene Beckerman's novel Love, Loss and What I Wore (1995) and the play of the same name written by Nora and Delia Ephron (2008).

What all the chapters provide is a glimpse into the long history of marriage discourses which, in their totality, paved the way to the 21st-century concept of marital relationships. This concept will be sure to stimulate further discourses and debates, especially since each generation has to redefine the existent social norms to adequately adjust them to its own necessities and demands. The editors hope that these discourses will contribute to a future form of marriage that is truly equal and might thereby also gain more accuracy in regards to the romantic images related to it.

\section{Works Cited}

Alexander, Kirsty, Catherine Eschle, Jenny Morrison and Mairi Tulbure. "Feminism and Solidarity on the Left: Rethinking the Unhappy Marriage Metaphor." Political Studies 67, no. 4 (2019): $972-991$.

Anitha, Sundari and Aisha Gill. "Coercion, Consent and the Forced Marriage Debate in the UK.” Feminist Legal Studies 17 (2009): 165-184.

Banks, Olive. Becoming a Feminist: The Social Origins of "First Wave" Feminism. Brighton: Wheatsheaf Books, 1986.

Bates, Laura. "How to Have a Feminist Wedding." The Guardian, June 28, 2014. https://www. theguardian.com/lifeandstyle/2014/jun/28/can-a-feminist-be-a-bride-laura-bates.

Bebel, August. Woman and Socialism. New York: Socialist Literature Co., 1910 [1879]. Accessed March 4, 2021. https://www.marxists.org/archive/bebel/1879/woman-social ism/index.htm.

Becker, Mary. "Patriarchy and Inequality: Towards a Substantive Feminism." University of Chicago Legal Forum 1 (1999): 21-88.

Bergoffen, Debra B. “Marriage, Autonomy, and the Feminine Protest." Hypatia 14, no. 4: The Philosophy of Simone de Beauvoir (1999): 18-35.

Bernard, Jessie. The Future of Marriage. New York: Bantam Books, 1972.

Blaisure, Karen R. and Katherine R. Allen. "Feminists and the Ideology and Practice of Marital Equality." Journal of Marriage and Family 57, no. 1 (1995): 5-19.

Bohr, Felix et al. "Ist das * jetzt Deutsch?" Der Spiegel, March 5, 2021. https://www.spiegel. de/panorama/gesellschaft/gendergerechte-sprache-der-kulturkampf-um-die-deutschesprache-a-ad32de9a-0002-0001-0000-000176138596. 
Brée, Sandra and Saskia Hin, eds. The Impact of World War I on Marriages, Divorces, and Gender Relations in Europe. London: Routledge, 2020.

Bois, Marcel and Frank Jacob, eds. Zeiten des Aufruhrs (1916-1921): Globale Proteste, Streiks und Revolutionen gegen den Ersten Weltkrieg und seine Auswirkungen. Berlin: Metropol, 2020.

Borutta, Manuel and Nina Verheyen. "Vulkanier und Choleriker? Männlichkeit und Emotion in der deutschen Geschichte 1800-2000." In Die Präsenz der Gefühle: Männlichkeit und Emotion in der Moderne, edited by Manuel Borutta and Nina Verheyen, 11-39. Bielefeld: Transcript, 2010.

Brake, Elizabeth. Minimizing Marriage: Marriage, Morality, and the Law. Oxford: Oxford University Press, 2012.

Bykova, Marina F. and Kenneth R. Westphal, eds. The Palgrave Hegel Handbook. Cham: Palgrave, 2020.

Cage, E. Claire. Unnatural Frenchmen: The Politics of Priestly Celibacy and Marriage, 1720-1815. Charlottesville, VA: University of Virginia Press, 2015.

Elaman, Sevinç. "A Feminist Dialogic Reading of the New Woman: Marriage, Female Desire and Divorce in the Works of Edith Wharton and Halide Edib Adıvar." PhD diss., University of Manchester, 2012.

Engels, Friedrich. Der Ursprung der Familie, des Privateigenthums und des Staats. Hottingen-Zurich: Verlag der Schweizerischen Volksbuchhandlung, 1884. Accessed March 4, 2021. https://www.marxists.org/archive/marx/works/1884/origin-family/ch02d. htm.

Eskridge, William N., Jr. “A History of Same-Sex Marriage.” Virginia Law Review 79, no. 9 (1993): 1419-1513.

Eskridge, William N. and Christopher R. Riano. Marriage Equality: From Outlaws to In-Laws. New Haven, CT: Yale University Press, 2020.

Fulford, Tim. "Poetic Flowers/Indians Bowers." In Romantic Representations of British India, ed. Michael Franklin, 113-130. New York: Routledge, 2006.

Grayzel, Susan A. Women's Identities at War: Gender, Motherhood, and Politics in Britain and France During the First World War. Chapel Hill, NC: The University of North Carolina Press, 1999.

Grossbard, Shoshana. The Marriage Motive: A Price Theory of Marriage. New York: Springer, 2015.

Grossi, Renata. Looking for Love in the Legal Discourse of Marriage. Canberra: Australian National University Press, 2014.

Hale, Matthew. History of the Pleas of the Crown 1736, vol. 1, edited by Peter R. Glazebrook. London: Professional Books, 1971.

Hall, Lesley. “'Good Sex': The New Rhetoric of Conjugal Relations.” In The Facts of Life: The Creation of Sexual Knowledge in Britain 1650-1950, edited by Roy Porter and Lesley Hall, 202-223. New Haven, CT: Yale University Press, 1995.

Heilmann, Ann. New Woman Strategies: Sarah Grand, Olive Schreiner, Mona Caird. Manchester: Manchester University Press, 2004.

Jacob, Herbert. Silent Revolution: The Transformation of Divorce Law in the United States. Chicago: University of Chicago Press, 1988.

Josephson, Jyl. "Citizenship, Same-Sex Marriage, and Feminist Critiques of Marriage." Perspectives on Politics 3, no. 2 (2005): 269-284. 
Jureit, Ulrike. "Zwischen Ehe und Männerbund: Emotionale und sexuelle Beziehungsmuster im Zweiten Weltkrieg." WerkstattGeschichte 22 (1999): 61-73.

Landes, Joan B. “Hegel's Conception of the Family." Polity 14, no. 1 (1981): 5-28.

LeGates, Marlene. "The Cult of Womanhood in Eighteenth-Century Thought."

Eighteenth-Century Studies 10, no. 1 (1976): 21-39.

Levine, Philippa. “'So Few Prizes and So Many Blanks': Marriage and Feminism in Later Nineteenth Century England.” Journal of British Studies 28, no. 2 (1989): 150-174.

Lovett, Margot. "On Power and Powerlessness: Marriage and Political Metaphor in Colonial Western Tanzania." The International Journal of African Historical Studies 27, no.2 (1994): 273-301.

Mazurek, John. The Road to Marriage Equality. New York: Rosen Publishing, 2018.

Moses, Julia. "Introduction: Making Marriage 'Modern'." In Marriage, Law and Modernity: Global Histories, edited by Julia Moses, 1-23. London: Bloomsbury, 2017.

Mosse, George L. The Image of Man: The Creation of Modern Masculinity. New York: Oxford University Press, 1996.

Nock, Steven L. Marriage in Men's Lives. Oxford: Oxford University Press, 1998.

Paterson, Laura L. and Georgina Turner. "Approaches to Discourses of Marriage." Critical Discourse Studies 17, no. 2 (2020): 133-137.

Potter, Edward T. Marriage, Gender, and Desire in Early Enlightenment German Comedy. Cambridge: Cambridge University Press, 2013.

Probert, Rebecca, Joanna Miles and Perveez Mody. "Introduction.” In Marriage Rites and Rights, edited by Joanna Miles, Perveez Mody and Rebecca Probert, 1-16. Oxford: Hart Publishing, 2015.

Putz, Christa. Verordnete Lust: Sexualmedizin, Psychoanalyse und die "Krise der Ehe", 1870-1930. Bielefeld: Transcript, 2011.

Quek, Kaye. Marriage Trafficking: Women in Forced Wedlock. London: Routledge, 2018.

Randall, Melanie, Jennifer Koshan and Patricia Nyaundi, eds. The Right to Say No: Marital Rape and Law Reform in Canada, Ghana, Kenya and Malawi. Oxford: Hart, 2017.

Reynolds, Sian. Marriage and Revolution: Monsieur and Madame Roland. New York/Oxford: Oxford University Press, 2012.

Richter, Hedwig and Kerstin Wolff, eds. Frauenwahlrecht: Demokratisierung der Demokratie in Deutschland und Europa. Hamburg: Hamburger Edition, 2018.

Schmugge, Ludwig. Marriage on Trial: Late Medieval German Couples at the Papal Court. Washington, DC: Catholic University of America Press, 2012.

Seidel Menchi, Silvana. "Introduction." In Marriage in Europe, 1400-1800, edited by Silvana Seidel Menchi, 3-30. Toronto: University of Toronto Press, 2016.

Simmons, Christina. Making Marriage Modern: Women's Sexuality from the Progressive Era to World War II. New York: Oxford University Press, 2009.

Smart, Carol. The Ties that Bind: Law, Marriage and the Reproduction of Patriarchal Relations. Routledge: London, 1984.

Smock, Pamela J. "The Wax and Wane of Marriage: Prospects for Marriage in the 21st Century." Journal of Marriage and Family 66, no. 4 (2004): 966-973.

Steinbach, Anja. "Mutter, Vater, Kind: Was heißt Familie heute?" Aus Politik und Zeitgeschichte 67, no. 30-31 (2017): 4-8.

Stone, Lawrence. Broken Lives: Separation and Divorce in England, 1660-1857. Oxford University Press, Oxford, 1993. 
Streichhahn, Vincent and Frank Jacob, eds. Geschlecht und Klassenkampf: Die "Frauenfrage" aus deutscher und internationaler Perspektive im 19. und 20. Jahrhundert. Berlin: Metropol, 2020.

Sutter Fichtner, Paula. "Dynastic Marriage in Sixteenth-Century Habsburg Diplomacy and Statecraft: An Interdisciplinary Approach.” The American Historical Review 81, no. 2 (1976): 243-265.

Wells, H. G. Marriage. Auckland, NZ: The Floating Press, 2011 [1912].

Wilkinson, Kathryn. "Hegel, The Sacrifice of Personality and Marriage.” PhD diss., University of Sheffield, 2006.

Willoughby, Brian J. The Millennial Marriage. London/New York: Routledge, 2020.

Ziegler, Mary. "An Incomplete Revolution: Feminists and the Legacy of Marital-Property Reform." Michigan Journal of Gender \& Law 19, no. 2 (2013): 259-292.

Žižek, Slavoj. Hegel im verdrahteten Gehirn. Translated by Frank Born. Frankfurt am Main: Fischer, 2020.

Žižek, Slavoj. “Hegel on Marriage.” E-Flux Journal 34 (2012). Accessed March 4, 2021. http:// worker01.e-flux.com/pdf/article_8951758.pdf. 